Recent work by Smith, Andrewes, and Laidlaw is highly suggestive that this may be the true solution of the problem. These workers have succeeded in producing influenza in ferrets and from ferrets to ferrets thereafter by the nasal route, using bacteria-free filtrate from nasal washings from influenza patients. Ferrets were not infected by similar material from non-influenzal persons or from persons who had a cold in the head. Serum from convalescent humans protected other ferrets from infection for several months.

\section{A Pleomorphic Virus ?}

If influenza is a virus disease, is it not possible to assume that the virus may be of several types, just as the pneumococcus and the meningococcus are of several " types," and that the different clinical forms of disease may depend on which type of virus is the predominant infecting agent, or even that the virus may exhibit mutation from one type to another, or again that there may be several allied viruses in the sense that typhoid and the various paratyphoid bacilli are allied but yet sufficiently different, in that they do not confer crossimmunity the one to the other ? This might help to explain the rather anomalous questions of post-influenzal immunity as, for example, the apparent clinical fact that people who had suffered from influenza in 1890 and who were alive in 1918 for the most part escaped infection in that year. In contrast with this we find that annual influenzal attacks are a commonplace. May it not be that this hypothetical virus attacks by preference the mucous membranes or the nervous system, and that at times of epidemics the virus is more deadly, and so damages the mucosae, or so impairs the balance between the sympathetic and parasympathetic nervous systems, or other parts of the central nervous system, that invasion by secondary pathogenic organisms is made easy, and resistance to these invaders is made difficult or impossible by reason of upset and damage to the nervous and metabolic processes which regulate the healthy protective mechanism against bacterial invasion?

It has been suggested by Smith Jelliffe that many of the clinical phenomena of influenza-the headache, the sweats, the pains, the bradycardia, the depression, and the tendency to exudate formation in the lungs and elsewhere-may be explained by a profound disturbance in the balance between the autonomous and sympathetic nervous systems. It seems reasonable. Certainly many cases of post-influenzal bradycardia so marked as to suggest heart-block have been shown by the electrocardiograph to be due merely to vagus over-activity, though in other cases true heart-block and other such disturbances of rhythm as flutter and fibrillation may occur with obvious myocardial damage. May not the apparent connexion between poliomyelitis, cerebro-spinal meningitis and encephalitis, and influenza be explained by the possibility that the one prepares the ground for the invasion by the other, and vice versa ; or may not the factor of symbiosis explain some of the secondary invasions and differences in virulence? Hamer has shown that on one occasion when a cerebro-spinal fever epidemic followed closely on an influenzal epidemic the incidence of the cerebro-spinal meningitis was ten times greater among those who had had influenza than the statistical expectation warranted, while Brorström in 1910 emphasized the relation between poliomyelitis and influenza.

\section{Treatment and Prophylaxis}

It remains but to say a very few words about treatment. Here I am on difficult ground. The treatment of the attack of influenza is peculiarly the province of the general practitioner; the number of different remedies that have been extolled shows clearly that there is no specific. All are agreed that early and prolonged rest in bed is all-important, and most of us have our pet prescriptions, usually based on aspirin and cafieine, whereby we hope to relieve the more intolerable of the symptoms ; but few of us, I fancy, claim in any way to cure influenza. The prospect of doing good by the use of convalescent serum is attractive but beset with difficulty. We have done a little work in this direction within the hospital, and hope to do more when the opportunity offers. At present it can only be said that research in this direction offers at least a possibility of some day providing a valuable therapeutic agent. The only other question that occurs to me is the possibility of doing good in times of epidemic influenza by wholesale prophylactic vaccination against the secondary invaders. I myself am convinced that therapeutic vaccination when the secondary invasion has occurred is utterly useless, but I feel that the secondary invasion might perhaps be avoided if the individual were protected by a previous course of mixed vaccine against the potential invaders.

\section{THE: EPIDEMIOLOGY OF SCARLET FEVER IN A LANDWARD AREA}

\author{
BY
}

JOHN RIDDELL, M.B., CH.B., D.P.H.

ASSISTANT MEDICAL OFFICER OF HEALTH, COUNTY OF STIRLING

The recent publication by the Medical Research Council of an Epidemiological Study of Scarlet Fever in England and Wales since 1900 , by Hilda M. Woods, raises many points of great interest and importance. Perhaps the most striking conclusion to be drawn is that the present low mortality rate is probably only temporary, and that a recurrence of the more malignant type of scarlet fever may be expected. In view of this it would appear wise to concentrate our efforts now on elucidating any factors which might affect the incidence or mortality of the disease, in order that we may be prepared for, and, if possible, prevent, this future source of anxiety. It, is hoped that this study, while making no pretension to be exhaustive, may lead to speculation and possibly further investigation into some unexplored aspects of the subject.

The cases dealt with comprise all the notifications of scarlet fever in the landward area of Stirlingshire during the ten years 1921-30. As mentioned in the Medical Research Council's report, ${ }^{1}$ notifications do not, of course, form an infallible basis for statistical conclusions, owing, in a landward area especially, to the number of missed cases and other causes, but in a study. such as this the effect of these errors can at most only be slight.

\section{Periodicity}

In the ten years covered no decision can be reached with regard to the periodicity of the disease in this area, but it would appear to conform to the usual five to seven years. In order not to break up the periods of greatest incidence, each year has been taken as commencing on July 1 st and ending on June 30 th succeeding. Table I shows a minimum incidence in 1922-3, rising to a maximum in 1925-6, and falling to a minimum again in 1927-8 - that is, a period of five years between the two minima.

If the cases are now subdivided into age groupscorresponding roughly to pre-school children, school children, and adults-the interesting fact emerges that there is less annual variation in the incidence among adults, and that there is also a tendency for a "lag" 
to occur-that is, the minimum incidence comes a year later, the maximum a year later, and the following minimum two years later, than in the case of children.

TABLE I.-Annual Incidence

\begin{tabular}{|c|c|c|c|c|c|c|c|c|c|c|c|}
\hline 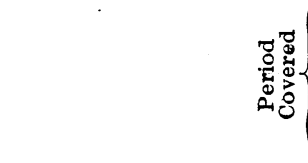 & 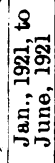 & 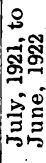 & 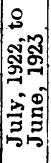 & 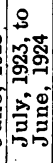 & 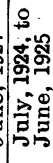 & 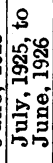 & 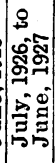 & 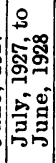 & 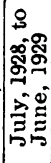 & 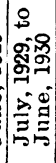 & 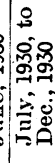 \\
\hline All cases & 277 & 180 & 149 & 207 & 381 & 449 & 429 & 217 & 260 & 258 & 117 \\
\hline Ages 0 to 4 yrs. 11 mos. & & 51 & 40 & 57 & 98 & 128 & 107 & 52 & 59 & 56 & \\
\hline Ages 5 yrs. to 13 yrs. $11^{\circ}$ mos. & & 101 & 84 & 126 & 225 & 268 & 243 & 111 & 156 & 163 & \\
\hline Ages 14 years and over & & 28 & 25 & 24 & .58 & 53 & 79 & 54 & 45 & 39 & \\
\hline
\end{tabular}

TABLE II.-Seasonal Incidence

\begin{tabular}{|c|c|c|c|c|c|c|c|c|c|c|c|c|}
\hline 窇 & $\stackrel{\overrightarrow{3}}{\overrightarrow{3}}$ & $\stackrel{x}{z}$ & 莒 & $\stackrel{\dot{\Delta}}{0}$ & $\begin{array}{l}\overrightarrow{2} \\
\dot{z}\end{array}$ & $\begin{array}{l}\dot{0} \\
\Phi \\
\Phi\end{array}$ & בี่ & $\stackrel{0}{0}$ & 荧 & $\overrightarrow{\underline{Z}}$ & $\stackrel{\vec{\Xi}}{\stackrel{\Delta}{z}}$ & \\
\hline All cases ... & 158 & 219 & 275 & 342 & 270 & 275 & 322 & 284 & 205 & 202 & 187 & \\
\hline Ages 0 to 4 yrs. 11 mos... & 38 & 59 & 73 & 91 & 63 & 65 & 63 & 81 & 45 & 55 & 49 & \\
\hline $\begin{array}{l}\text { Ages } 5 \text { yrs. to } 13 \text { yrs. } \\
11 \text { mos. } \\
\text { Ages } 14 \text { yrs. and over... }\end{array}$ & $\begin{array}{l}95 \\
25\end{array}$ & $\begin{array}{r}134 \\
26\end{array}$ & $\begin{array}{r}172 \\
30\end{array}$ & $\begin{array}{r}212 \\
41\end{array}$ & $\begin{array}{r}172 \\
35\end{array}$ & $\begin{array}{r}149 \\
62\end{array}$ & $\begin{array}{r}195 \\
67\end{array}$ & $\begin{array}{r}159 \\
44\end{array}$ & $\begin{array}{r}104 \\
56\end{array}$ & $\begin{array}{r}110 \\
37\end{array}$ & $\begin{array}{r}112 \\
26\end{array}$ & \\
\hline
\end{tabular}

Taking all cases reported two peaks are evident-one in October and another in January. If, however, the cases are divided into age groups as before, there is found to be a variation. The pre-school children and school children show a maximum incidence in October,. with minor peaks in February and January respectively. There is here no evidence of mass infection among the school children due to resuming school at the end of August. The adult group shows only a very slight increase in October, but a maximum incidence in December and January, with another peak in March. The period of maximum liability to infection among adults would thus appear to follow that of children by two to three months. Both annual and seasonal incidence, therefore, vary with age.

It has been shown by the Registrar-General ${ }^{2}$ that the maximal seasonal incidence of mortality in scarlet fever appears to be changing from October and November to January, and that "whereas October is the last month of increasing notifications, increase of deaths continues until January, and until May the proportion of deaths remains much higher than that of notifications." Hilda Woods, dealing with London Eastern Hospital cases from 1905 to $1914,{ }^{1}$ points out that there was a greater tendency for deaths to occur in cases arising in April, May, and June. She also shows that the fatality rate declines with age until adolescence is reached, but tends to rise in adults, and that the relative importance of mortality in later life is becoming progressively greater. This was also found by Pope. ${ }^{3}$ Can later seasonal incidence and increased spring mortality be explained by the fact that the average age of incidence of scarlet fever is becoming progressively greater, possibly due to better housing conditions and earlier and more general segregation of cases?

\section{Variation of Incidence with Size of House}

Annual and scasonal incidence do not vary with size of house ; total incidence and age and sex incidence do. Table III gives, first, the absolute number of cases in each size of house, then this number stated as a percentage, and then the percentage of the general population resident in each size of house. These latter percentages are calculated from the 1921 and 1931 census figures. The cases are then divided into two groups according to age-those under 14 years and those 14 years and over. In the case of the children the population at risk is taken as the number of children in the 2,859 houses from which all the cases were drawn, and in the case of the adults the number of adults in those houses. These numbers are taken as samples in the absence of figures relating to the housing and age distribution of the general population.

Table III.-Effect of Size of House on Total and Age Incidence

\begin{tabular}{|c|c|c|c|c|c|c|c|c|c|c|}
\hline \multirow{2}{*}{\multicolumn{2}{|c|}{$\begin{array}{c}\text { No. of } \\
\text { Apartments }\end{array}$}} & \multicolumn{3}{|c|}{ All Cases } & \multicolumn{3}{|c|}{$\begin{array}{l}\text { Cases } 0 \text { to } \\
13 \text { Yrs. } 11 \text { Mos. }\end{array}$} & \multicolumn{3}{|c|}{$\begin{array}{c}\text { Cases } 34 \text { Yrs. and } \\
\text { Over }\end{array}$} \\
\hline & & No. & $\%$ & \% Pop. & No. & $\%$ & \% Pop. & No. & $\%$ & \% Pop. \\
\hline I $\ldots$ & $\ldots$ & 211 & 7.3 & 6.3 & 197 & 8.1 & 6.9 & 14 & 3.2 & 4.9 \\
\hline II $\ldots$ & $\ldots$ & 1,508 & 52.7 & 45.3 & 1,341 & 55.4 & 57.4 & 167 & 38.1 & 49.2 \\
\hline III $\ldots$ & $\ldots$ & 562 & 19.7 & 23 & $4: 0$ & 19.0 & 19.6 & 102 & 23.4 & 21.5 \\
\hline IV $\ldots$ & $\ldots$ & 239 & 8.4 & 10.1 & 193 & 8.0 & 7.3 & 46 & 10.6 & 8.5 \\
\hline Over IV & $\ldots$ & 339 & 11.9 & 15.2 & 231 & 9.5 & 8.8 & 108 & 24.7 & 15.9 \\
\hline
\end{tabular}

It is seen from the figures for all cases that the smaller the number of apartments in the house the greater the relative incidence of fever. When we consider the adults alone, however, we see that the reverse is the case, and when we take the children under 14 years we find an intermediate stage. Had it been possible to obtain figures for the age groups 0 to 4 years 11 months and 5 years to 13 years 11 months separately, would this have shown the younger group as causing the increased incidence in the small houses, with the school children an intermediate group? Increased chances of infection and of acquired immunity in the smaller apartment house would suggest that this would be likely.

That earlier infection does occur in the smaller house is shown in Table IV, where the average ages of the cases under 14 years in each size of house are given. In calculating the ages all children in each year group were taken as being concentrated at the centre of the groupfor example, all between 3 and 4 years were counted as 3 years 6 months. These findings agree with the results of Halliday in his investigation of measles cases. ${ }^{4}$

Table IV.-Size of House, Overcrowding, and Age Incidence

\begin{tabular}{|c|c|c|c|c|c|}
\hline 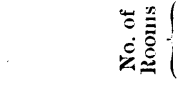 & I & II & III & IV & Over IV \\
\hline $\begin{array}{c}\text { Averase age of } \\
\text { cases } \\
\text { Persons per } \\
\quad \text { apartment }\end{array}$ & 6 yrs. $1 \mathrm{mo}$. & $6 \mathrm{grs} .7 \mathrm{mos}$. & i yrs. 4 mos. & 7 yrs. 1 mo. & $7 \mathrm{yrs} .7 \mathrm{mos}$. \\
\hline Cases... $\quad \ldots$ & 3.7 & 2.3 & 1.6 & 1.1 & 0.8 \\
\hline General pop. & 3.2 & 2.3 & 1.6 & 1.2 & \\
\hline
\end{tabular}

The question now arises, Is the earlier age incidence in the small apartment house due to overcrowding? In Table IV are given the persons per apartment in the case of all the notifications, and corresponding figures for the general population, calculated from the 1921 and 1931 census returns. Except in the case of the one-apartment house there is no more overcrowding in the houses in which scarlet fever occurred than in the corresponding houses of the general population.

As regards sex variation (Table V), a larger percentage of the cases among girls under 14 years comes from the smaller type of house than is the case with boys. Assum. ing that the sex constitution is the same in each size of 
house, this would suggest that in the smaller type of house girls are more liable to infection than boys, while the reverse is the case in the larger houses.

TABL.E V.-Size of House and Sex Incidence in Children

\begin{tabular}{rr|c|c|c|c}
\hline $\begin{array}{r}\text { II } \\
\text { Percentage number of }\end{array}$ & 7.8 & 53.3 & III & IV & Over IV \\
\hline $\begin{array}{c}\text { boys } \\
\text { Percentage number of } \\
\text { girls }\end{array}$ & 8.5 & 57.2 & 180 & 7.8 & 8.5
\end{tabular}

Variation of Incidence with Sex and Age

TABLE VI.-Sex and Age Incidence

\begin{tabular}{|c|c|c|c|c|c|c|c|c|c|c|c|c|c|c|c|c|}
\hline$\underset{0}{\infty}$ & 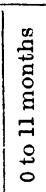 & 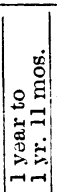 & $\begin{array}{l}0 \\
0 \\
0 \\
0 \\
0\end{array}$ & $\mid \begin{array}{r}0 \\
0 \\
0 \\
0 \\
0 \\
3\end{array}$ & 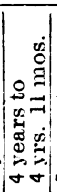 & 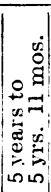 & $\underset{0}{\infty}$ & 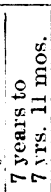 & 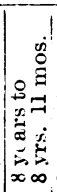 & 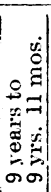 & 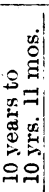 & 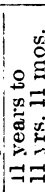 & 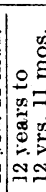 & 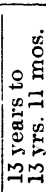 & 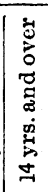 & 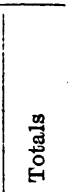 \\
\hline & 8 & 38 & 72 & & & 1 & 129 & 117 & 83 & 1 & 83 & 44 & 46 & 39 & 186 & \\
\hline & 17 & 40 & 67 & & 9 & 157 & 163 & 138 & 119 & 111 & 86 & 63 & 64 & 59 & 284 & \\
\hline
\end{tabular}

With the exception of the age group 2 years to 2 years 11 months, there is seen to be an excess of female cases throughout. This shows a true increase in susceptibility, because in the general population of this area there is an excess of males over females at all ages under 20, and also in the general population above that. The fact that a larger proportion of girls than boys come from houses with few apartments, and that the age incidence is earlier in these houses, would suggest that the age incidence in girls should be earlier than in boys. Such is not the case, however, as is seen from Table VI, where 56.6 per cent. of the boys are under 7 years, and only 52.1 per cent. of the girls. Also, in the case of boys the age of maximum incidence is in the fifth year, whereas in girls it is in the sixth year. The excess of female cases and the maximum age incidence at 5 to 6 years are the commonly accepted findings.

\section{SUMMARY}

1. The periodicity of scarlet fever in this area appears to be one of about five years.

2. Adults have an annual variation in incidence separate from that of children, and following that of children at about one year's interval.

3. While the maximum seasonal incidence in children is in October, with a smaller increase in January and February, the maximum in adults is in December and January, with a following increase in March.

4. The fewer the number of apartments in the house the higher the incidence of fever among children, but the lower among adults.

5. The smaller the house the earlier the average age of infection among children. This does not appear to be due to overcrowding per se.

6. Females are more liable to infection with scarlet fever than males, but girls are not affected until a later age than boys, though a larger proportion of their cases come from small apartment houses.

7. The maximum age of incidence for boys is $\mathbf{5}$ years, and for girls 6 years.

\section{REFERENCES}

${ }^{1}$ Woods, Hilda M.: Epidemiological Study of Scarlet Fever in England and Wales since 1900, Medical Research Council, Special Report Series No. 180, 1933.

1 Annual Report of Registrar-General, 1925, p. 97.

3 Pope, S. A.: Amer. Journ. Hyg., 1926, vi, 389 .

- Halliday, J.: An Inquiry into the Relationship between Housing Conditions and the Incidence and Fatality of Measles, Medical Research Council, Special Report Series No. 120, 1028.
THE AETIOLOGY OF HEART DISEASE

BY

C. BRUCE PERRY, M.D., M.R.C.P.

ASSISTANT PHYSICIAN, BRISTOL GENERAL HOSPITAL

An analysis of the cases of organic heart disease seen by the late Dr. Carey Coombs in the wards of the Bristol General Hospital during the years 1918 to 1929 showed that acute rheumatism was the aetiological factor in over 55 per cent. Further, a three-year survey of the incidence of acute rheumatic heart disease in Bristol and the surrounding counties ${ }^{1}$ provided strong evidence that the incidence of this disease was very much higher in the city than in the counties. For these reasons it appeared desirable to Dr. Coombs that an attempt should be made to assess the part played by rheumatism in the causation of heart disease in other parts of Great Britain. The trustees of the R. L. St. J. Harmsworth Fund interested themselves in this investigation, and by their help it has been possible to obtain the figures of the cardiac cases admitted to various hospitals of Great Britain for the year 1932. Information has been received from the following: Royal Infirmary, Aberdeen ; Royal Victoria Hospital, Belfast ; General Hospital, Birmingham ; General Hospital, Bristol ; Royal Infirmary, Bristol ; Royal Infirmary, Cardiff ; Western Infirmary, Glasgow ; National Hospital for Diseases of the Heart, London; Royal Infirmary, Liverpool ; Middlesex Hospital ; Royal Victoria Infirmary, Newcastle ; Norfolk and Norwich Hospital, Norwich ; and Royal Hospital, Sheffield.

The classification adopted was as follows:

1. Congenital heart disease.

2. Rheumatic heart disease. In this group were included not only cases of heart disease with a history of rheumatism, chorea, tonsillitis, or scarlet fever, but also cases without any such history, yet conforming in type to the rheumatic pattern-namely, cases of (a) ventricular enlargement with. mitral incompetence under the age of 40 ; (b) mitral stenosis with or without incompetence ; (c) aortic incompetence with or without stenosis under the age of 30 ; and $(d)$ acute fibrinous pericarditis. The inclusion of such cases in this group was, of course, conditional on the absence of any alternative aetiology.

3. Ulcerative endocarditis. In this group were placed all cases of infective lesions of the endocardium not already included under rheumatic or syphilitic; thus it included all cases of acute, subacute, and chronic bacterial endocarditis, endocarditis lenta, etc.

4. Cardiac syphilis. This group comprised cases of aortic incompetence, aneurysm, aortitis, and angina with a history of syphilis, positive Wassermann reaction, or the presence of signs of other syphilitic lesions such as tabes dorsalis.

5. Thyrotoxic heart disease. In this group were placed all cases with physical signs or symptoms of heart disease with evidence of past or present thyrotoxicosis.

6. Hyperpiesis. Systolic blood pressures of $200 \mathrm{~mm}$. $\mathrm{Hg}$ and over, even if only reported on one occasion, qualified for admission to this group, whether the patient also exhibited signs of arterial degeneration or not.

7. Senile cardiosclerosis. This term covered all cases of arteriosclerotic or " senile" heart disease, even though the " senility" was premature. The wcrd ". decrescent" was considered, but rejected for various reasons. This group, of course, included the majority of cases of coronary thrombosis.

8. Functional. All cases of heart disease with no ascertainable organic basis were placed in this group, which included such diseases as " D.A.H.," paroxysmal tachycardia without organic lesion, sino-auricular block, etc. 